\title{
Habitat use by the Vulnerable greater spotted eagle Aquila clanga interbreeding with the lesser spotted eagle Aquila pomarina in Estonia
}

\author{
Asko Lõhmus and Ülo Väli
}

\begin{abstract}
Major threats to the Vulnerable greater spotted eagle Aquila clanga are habitat loss and hybridization with the lesser spotted eagle Aquila pomarina, but no quantitative studies have been carried out to understand these processes. In Estonia the known remaining A. clanga population comprises only five pure and nine mixed pairs. We describe their habitat at the scale of both the home range and nest site, and use logistic regression models for comparisons with random forest plots and nest sites of $A$. pomarina. The territories of $A$. clanga were characteristically near waterbodies, where the species' nesting preference was for dense forest with a pronounced old-growth structure. Habitats of the two species were distinct at both spatial scales. Open natural
\end{abstract}

landscapes were favoured by $A$. clanga but avoided by $A$. pomarina. Within its home range $A$. clanga occupied old wet stands containing black alder, birch and pine, whereas A. pomarina preferred old spruce stands. Multivariate models, which summarized these differences between the two species, did not reveal distinct habitat features of mixed pairs compared with $A$. clanga pairs. Hence, interbreeding pairs may occupy previous $A$. clanga territories, and these deserve similar protection to those currently inhabited by $A$. clanga pairs.

Keywords Aquila clanga, Aquila pomarina, Estonia, greater spotted eagle, habitat selection, hybridization, lesser spotted eagle, nest sites, wetlands.

\section{Introduction}

The greater spotted eagle Aquila clanga is a globally threatened raptor sparsely distributed across a large area of temperate Eurasia (BirdLife International, 2000). It is categorized as Vulnerable on the IUCN Red List (IUCN, 2004). Habitat alterations through forestry and drainage activities have been identified as major threats, but the species' ecological requirements and adaptability to environmental changes are still poorly known (Meyburg et al., 2001). Most descriptions of breeding habitat are either general landscape characterizations (Cramp \& Simmons, 1980; Malchevskij \& Pukinskij, 1983; Dombrovski et al., 2000; Mischenko et al., 2001) or anecdotal descriptions of one or a few nest sites (Glotov, 1959; Shepel, 1992; Ivanovsky, 1996; Dombrovski et al., 2000). The only detailed descriptive study is by Pugacewicz (1995), focusing on 18 nest sites of nine pairs in north-eastern Poland. The only comparison of

Asko Lõhmus (Corresponding author) and Ülo Väli* Institute of Zoology and Hydrobiology, Centre of Basic and Applied Ecology, University of Tartu, Vanemuise 46, 51014 Tartu, Estonia. E-mail Asko.Lohmus@ut.ee

${ }^{*}$ Current address: Institute of Zoology and Botany, Riia 181, 51014 Tartu, Estonia.

Received 21 January 2004. Revision requested 7 June 2004. Accepted 13 August 2004. nest sites and available habitat, looking at 13 nest sites in the Bryansk region, Russia, is a short note by Romanov (2001).

In Eastern Europe the species is sympatric with the lesser spotted eagle Aquila pomarina. Uniquely among wild raptor populations, these two species frequently hybridize (Zhezherin, 1969; Panov, 1989; Lõhmus \& Väli, 2001; Dombrovski, 2002), as confirmed recently by morphological and genetic analyses (Väli \& Lõhmus, 2004). Hybridization may pose a threat to the less numerous $A$. clanga, but the underlying mechanisms and possible conservation implications are unclear. While non-specific mate choice is the immediate cause of the formation of mixed species pairs, other factors may be operating. Habitat loss, in addition to its direct effect, may force the two species to breed in closer proximity and thus increase the frequency of hybridization.

Given the need for a greater understanding of the impact of hybridization, we explored the habitat relationships of A. clanga in Estonia, where one of the two remaining populations in the European Union breeds. The taxonomic status of $c .300$ pairs of spotted eagles of both species (50\% of the national total) has been monitored, revealing extensive hybridization in a situation where A. pomarina is at least 20 times more numerous than $A$. clanga (Väli \& Lõhmus, 2000, 2004). In this study we describe $A$. clanga habitat at two scales: 
the species' home range and nest site. At the home range (i.e. macrohabitat) scale we sought to determine the species' preferences by comparing the land cover of nesting territories with that of random plots, and to study segregation between $A$. clanga and A. pomarina we compared the land cover of nesting territories of the two species. At the nest site (i.e. microhabitat) scale, we examined preferences by comparing $A$. clanga nest sites and random plots, and to examine segregation between the two species we used all $A$. clanga nest sites and the nearest $A$. pomarina nest to each. We also compared the habitats of pure and hybrid pairs to elucidate the mechanism behind hybridization and to establish conservation needs for the nest sites of mixed pairs.

\section{Methods}

\section{Habitats}

Since the late 1980s nesting territories (an area occupied by a pair of mated birds over successive years; Steenhof, 1987) and nests of spotted eagles throughout Estonia have been mapped. We examined all 14 nesting territories of $A$. clanga where nests have been found: five pure pairs and nine mixed pairs (i.e. with parents of different species). For comparison, we considered 143 A. pomarina nesting territories (Väli, 2003; Väli et al., 2004) and randomly selected forest plots. To avoid pseudoreplication we only used the most recently occupied nest from each nesting territory for home range scale analyses. At the nest site scale we included all 22 known A. clanga nests (within the 14 nesting territories) to increase the accuracy of the analysis. This did not violate the assumption of sample independence because nests in the same territory were 390-1,110 m (median $590 \mathrm{~m}$ ) from each other, whereas nest sites are selected at a much smaller scale by the birds. The sampling scheme is summarized in Table 1.

At the home range scale we followed methods previously applied to A. pomarina (Väli et al., 2004). Land cover was examined within a $2-\mathrm{km}$ radius of nest trees (of both species) and of 143 random points within the forest, using the CORINE Land Cover digital map, which is based on satellite images for 1993-1995 (Meiner, 1999). The $2 \mathrm{~km}$ distance incorporates most foraging flights of breeding spotted eagles (Komischke et al., 2001; Scheller et al., 2001; A. Lõhmus \& Ü. Väli, pers. obs.). After exploring the intercorrelations of land cover variables, we selected for further analysis: (1) the area of forest where the species nest, (2) the open natural lands (i.e. floodplain meadows, transitional woodland/scrub, open fens and bogs) that are the preferred foraging habitats of $A$. clanga (Galushin, 1962; Pugacewicz, 1995), and (3) the reciprocal Simpson's index of landscape heterogeneity, calculated from the 20 original CORINE land cover types (all artificial surface types were pooled) as $D=\Sigma\left(p_{i}^{2}\right)^{-1}$, where $p_{i}$ is the relative area of land cover type $i$. Using recent topographic maps (mostly at a scale of 1:10,000) we also measured the distances from each nest tree or random point to the nearest forest edge, field or meadow, house, road and water body (river or lake). Many distances were checked in the field and we made minor corrections in the few cases where map data and the real situation differed.

At the nest site scale we described $A$. clanga nest sites and three forest plots, in a random direction, 200, 500 and $700 \mathrm{~m}$ from each nest, and the nearest $A$. pomarina nest, to each of the $14 \mathrm{~A}$. clanga nesting territories. We also described $14 A$. pomarina nest sites randomly selected from the 143 A. pomarina nest sites. We measured the mean height, diameter at breast height and age (using standard dendrochronological techniques) of overstorey trees, and tree species composition within a 30-m radius of each nest. Given the importance of forest structural diversity for forest-dwelling raptors, we followed Lõhmus (2003) in calculating an index of old-growth forest structure as a sum of the following four indicators: (1) age structure of tree layer (1, even-aged; 2 , multiple canopy layers have started to develop; 3 , multi-cohort forest but no established gap dynamics; 4, multi-cohort

Table 1 Sampling design of the study in relation to its aims and spatial scales. See Appendix for a list of measured variables.

\begin{tabular}{|c|c|c|}
\hline & Home range (i.e. macrohabitat) scale & Nest site (i.e. microhabitat) scale \\
\hline Aim & Land cover within $2 \mathrm{~km}$ of and distances from: & $\begin{array}{l}\text { Forest composition and structure within } 30 \mathrm{~m} \text {, and } \\
\text { canopy closure and soil moisture within } 5 \mathrm{~m} \text { of: }\end{array}$ \\
\hline $\begin{array}{l}\text { To study preferences } \\
\quad \text { (compare } A \text {. clanga habitat } \\
\text { with random sites) }\end{array}$ & $\begin{array}{l}\text { All } 14 \text { known nesting territories of } A \text {. clanga and } \\
143 \text { random plots }\end{array}$ & $\begin{array}{l}\text { All } 22 \text { known } A \text {. clanga nests in } 14 \text { territories and } \\
3 \text { random plots per territory }\left(n=3^{*} 14=42\right)\end{array}$ \\
\hline $\begin{array}{l}\text { To study species segregation } \\
\text { (compare } A \text {. clanga habitat } \\
\text { with A. pomarina habitat) }\end{array}$ & $\begin{array}{l}\text { All } 14 \text { known nesting territories of } A \text {. clanga and } \\
143 \text { nesting territories of } A \text {. pomarina }\end{array}$ & $\begin{array}{l}\text { All } 22 \text { known } A \text {. clanga nests in } 14 \text { territories and the } \\
\text { nearest } A \text {. pomarina nest to each } A \text {. clanga } \\
\text { territory }(n=14)\end{array}$ \\
\hline
\end{tabular}


forest with canopy gaps of different sizes and different stages of regeneration); (2) the numbers of standing dead trees $(1,<5 \% ; 2,6-10 \% ; 3,>10 \%$ of living trees); (3) the numbers of $\operatorname{logs}(1,<5 \% ; 2,6-10 \% ; 3,>10 \%$ of living trees); (4) the maximum decay stage of coarse woody debris $(1$, hard wood, not easily penetrable with a knife; 2 , at least $1 \mathrm{~cm}$ of wood easily penetrable with a knife; 3, soft wood, crushable by hand). We visually estimated mean canopy closure (on a scale of 0-1) within $5 \mathrm{~m}$ of a nest tree or random point, and soil moisture on a four-point scale from dry (1) to wet (4).

\section{Statistical analysis}

After initial selection of habitat variables, we further reduced their number (Appendix) because of some strong intercorrelations. At the home range scale we used principal component analysis to reduce four of the five distances (to the nearest forest edge, field / meadow, house and road) to one principal component ('fragmentation') that accounted for $63 \%$ of the variation. At the nest site scale nine of the 12 variables were intercorrelated, and were therefore reduced to two independent principal components. The first component ('large spruce', accounting for $29 \%$ of total variation) distinguished between old spruce-dominated forests with large trees (high scores) and wet thickets of birch (low scores). The second principal component ('alder swamp', accounting for $19 \%$ of total variation) ranged from young secondary stands of grey alder to old black alder-dominated swamps. In total there were therefore
10 habitat variables (five at each scale, of which seven were original variables and three principal components, see Appendix and Table 2).

The contributions of habitat variables in distinguishing between $A$. clanga nest sites and random sites (i.e. habitat preferences) and between the nests sites of the two species were explored with multiple logistic regression. We used the approach proposed by Hosmer \& Lemeshow (1989): (1) We performed univariate analysis of each independent variable, omitting those having a likelihood-ratio test $P>0.25$. (2) We built a preliminary multivariate model with the remaining variables, omitting those not contributing to the model. (3) We built and explored a multivariate model with the final set of variables. Because of the small sample sizes and low test power, we accepted variables with $0.05<\mathrm{P}<0.1$ as marginally significant if these had clear biological relevance. All statistical analyses were performed with Statistica version 6.0 (StatSoft, Inc. 1984-2001).

\section{Results}

The home range of $A$. clanga was characteristically near waterbodies and open natural lands (Table 2). Distance to waterbodies clearly separated nest sites from random forest plots; a similar tendency in A. pomarina was less pronounced and not significant (Fig. 1a). The two species were well segregated in their use of open landscapes (Table 2), such that $A$. clanga tended to prefer natural areas, whereas A. pomarina avoided these (Fig. 1b). The mean percentage cover of agricultural land within

Table 2 Univariate logistic regression models for distinguishing nest sites of $A$. clanga from random sites (preferences) and from nest sites of A. pomarina (species segregation). See Table 1 for the sampling scheme, and Appendix for list of variables.

\begin{tabular}{|c|c|c|c|c|c|c|c|c|}
\hline \multirow[b]{2}{*}{ Independent variable } & \multicolumn{4}{|l|}{ Preferences } & \multicolumn{4}{|c|}{ Species segregation } \\
\hline & Coefficient \pm SE & Log-likelihood & $\chi^{2}$ & $\mathrm{P}$ & Coefficient \pm SE & Log-likelihood & $\chi^{2}$ & $\mathrm{P}$ \\
\hline \multicolumn{9}{|c|}{ Home range scale ( $n=14$ A. clanga, 143 random plots, 143 A. pomarina) } \\
\hline Constant & & -47.2 & & & & -47.2 & & \\
\hline$\%$ forest & $-0.0081 \pm 0.0160$ & -47.1 & 0.3 & 0.608 & $0.0049 \pm 0.0186$ & -47.2 & 0.1 & 0.793 \\
\hline$\%$ open natural land & $0.0298 \pm 0.0196$ & -46.1 & 2.1 & 0.148 & $0.0746 \pm 0.0265$ & -43.4 & 7.6 & $0.006^{1}$ \\
\hline Heterogeneity & $0.02 \pm 0.19$ & -47.2 & 0.0 & 0.918 & $-0.06 \pm 0.23$ & -47.2 & 0.1 & 0.783 \\
\hline Fragmentation (D1) & $-0.15 \pm 0.30$ & -47.1 & 0.3 & 0.611 & $-0.93 \pm 0.53$ & $-44.8^{2}$ & 3.1 & 0.076 \\
\hline Distance to water body $(\mathrm{km})$ & $-0.69 \pm 0.35$ & -44.3 & 5.8 & $0.016^{1}$ & $-0.51 \pm 0.37$ & -46.0 & 2.4 & 0.121 \\
\hline \multicolumn{9}{|c|}{ Nest site scale ( $n=22$ A. clanga, 42 random plots, 14 nearest $A$. pomarina $)$} \\
\hline Constant & & -41.2 & & & & & & \\
\hline$\%$ Scots pine & $-0.016 \pm 0.014$ & -40.3 & 1.7 & 0.196 & $0.0434 \pm 0.0409$ & -23.3 & 1.5 & 0.215 \\
\hline Large spruce (S1) & $1.38 \pm 0.44$ & -34.2 & 14.0 & $<0.001$ & $-0.60 \pm 0.45$ & -23.1 & 2.0 & 0.157 \\
\hline Alder swamp (S2) & $0.41 \pm 0.28$ & -40.1 & 2.2 & 0.137 & $0.45 \pm 0.31$ & -22.9 & 2.3 & 0.129 \\
\hline Old-growth structure & $0.64 \pm 0.17$ & -31.6 & 19.1 & $<0.001$ & $0.22 \pm 0.19$ & -23.3 & 1.5 & 0.221 \\
\hline Canopy closure & $1.71 \pm 1.42$ & -40.4 & 1.5 & 0.219 & $0.48 \pm 1.81$ & -24.0 & 0.1 & 0.790 \\
\hline
\end{tabular}

${ }^{1}$ Univariate models, which appeared to be better than any further multivariate developments. The constants are $-1.52 \pm 0.42$ for the preference model, and $-3.18 \pm 0.47$ for the species segregation model.

${ }^{2}$ Sample size for A. pomarina $=134$; Log-likelihood of constant $=-46.3$. 

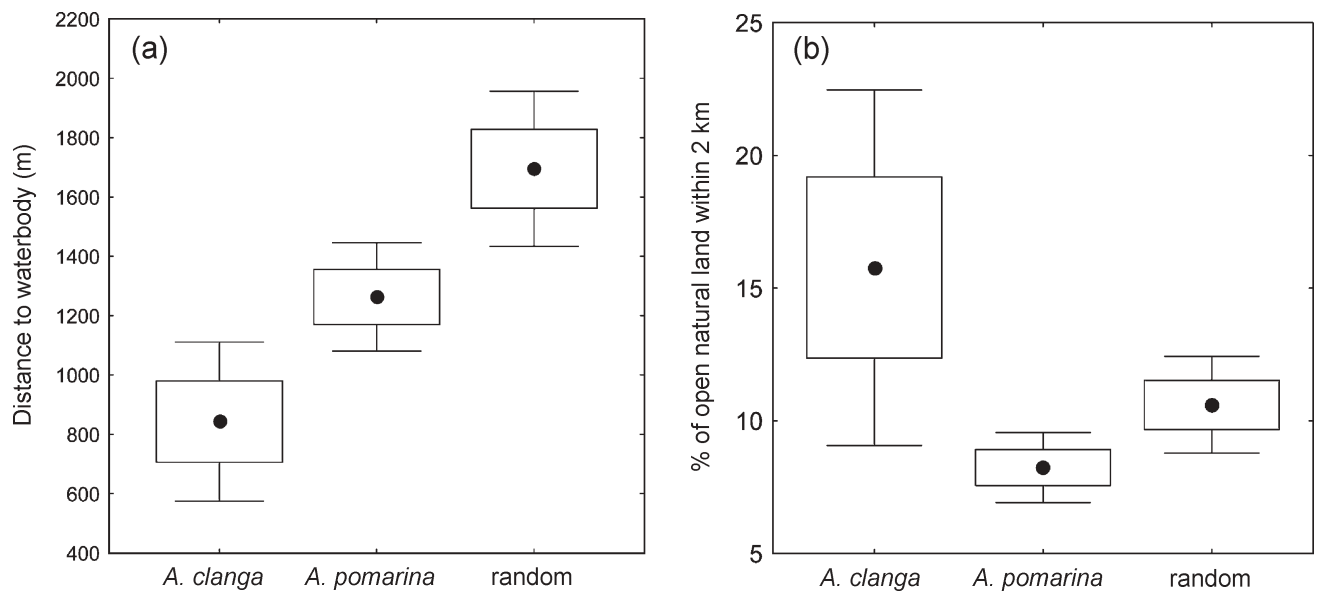

Fig. 1 Box plots of the average distance to the nearest waterbody (a) and the $\%$ of open natural lands (grasslands, bushy habitats, wetlands) within $2 \mathrm{~km}$ (b) of 14 A. clanga and 143 A. pomarina nests and 143 random forest points in Estonia. The boxes indicate the standard errors and the whiskers the $95 \%$ confidence intervals of the mean.

$2 \mathrm{~km}$ of $A$. clanga nests was $27.7 \pm \mathrm{SD} 17.2 \%(n=14)$. The tendency of the habitat of $A$. clanga to be less fragmented than that of A. pomarina ( $\mathrm{P}=0.076$; Table 2) disappeared in the multivariate analysis, and was probably related to the lower fragmentation of natural landscapes.

Within their generally wetland-dominated home ranges, $A$. clanga preferred old dense forest with a pronounced old-growth structure (Table 3). The importance of canopy closure became evident only after the two other important variables were taken into account (cf. the models in Tables 2 and 3). There was no clear gradual decrease in the likelihood of the eagles nesting at distances 200, 500 and $700 \mathrm{~m}$ from nests (Fig. 2), indicating that nest site selection occurred within $<200$ m radius.

The two species used different nest sites within the same landscapes (Table 3). A. clanga occupied wet forest containing black alder, birch and pine, whereas the nearest $A$. pomarina used significantly more old spruce forest stands. There was also a tendency towards a more pronounced old-growth structure at $A$. clanga nest sites. All these species-specific differences in nest stands became significant in the multivariate model (cf. Tables 2 and 3), indicating some interaction between them. Using the species-specific models at the two spatial scales did not reveal a clearly intermediate or otherwise separate position of mixed pairs within the A. clanga sample (Fig. 3).

\section{Discussion}

The main results of our study were the importance of natural landscapes and natural forest structure for A. clanga, its habitat partitioning with A. pomarina, and the lack of clear differences between the nest sites of pure and mixed species pairs. The accuracy of these findings may be influenced by the small sample size, as we had to reduce the number of habitat variables and pool the mixed and pure A. clanga pairs. However, we explored

Table 3 Multivariate logistic regression models for distinguishing the forest of 22 nest sites of A. clanga from 42 random sites and from 14 nearest nest sites of A. pomarina. See Table 1 for sampling scheme and Appendix for list of variables.

\begin{tabular}{|c|c|c|c|c|}
\hline Model or variable & Coefficient \pm SE & Log-likelihood & $\chi^{2}$ & $\mathrm{P}$ \\
\hline \multicolumn{5}{|c|}{ Preferences $\left(\right.$ Log-likelihood, model $\left.=25.9 ; \chi^{2}=30.5, \mathrm{P}<0.001\right)$} \\
\hline Intercept & $-8.02 \pm 2.48$ & & & \\
\hline Large spruce (S1) & $1.46 \pm 0.58$ & -30.1 & 8.3 & 0.004 \\
\hline Old-growth structure & $0.67 \pm 0.21$ & -32.9 & 13.8 & $<0.001$ \\
\hline Canopy closure & $4.25 \pm 2.11$ & -28.3 & 4.8 & 0.029 \\
\hline \multicolumn{5}{|c|}{ Species segregation (Log-likelihood, model $=18.0 ; \chi^{2}=12.2 ; \mathrm{P}=0.016$ ) } \\
\hline Intercept & $-2.89 \pm 2.02$ & & & \\
\hline$\%$ Scots pine & $0.013 \pm 0.085$ & -20.8 & 5.6 & 0.018 \\
\hline Large spruce (S1) & $-1.17 \pm 0.57$ & -20.5 & 5.1 & 0.024 \\
\hline Alder swamp (S2) & $0.67 \pm 0.37$ & -19.8 & 3.6 & 0.058 \\
\hline Old-growth structure & $0.44 \pm 0.26$ & -19.7 & 3.4 & 0.065 \\
\hline
\end{tabular}




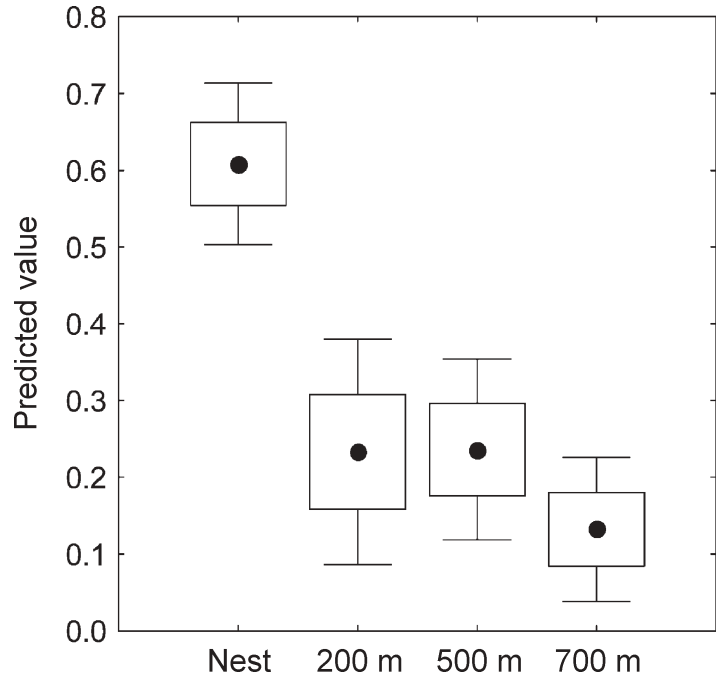

Fig. 2 Box plots of the mean probability values predicted by the preference model for nest sites of the greater spotted eagle $(n=22)$ and random sites 200, 500 and $700 \mathrm{~m}$ from the nests $(n=14$ for each category). The model was based on the occurrence of large spruce, old-growth structure and dense canopy (see Table 2). The boxes indicate the standard errors and the whiskers the $95 \%$ confidence intervals of the mean.

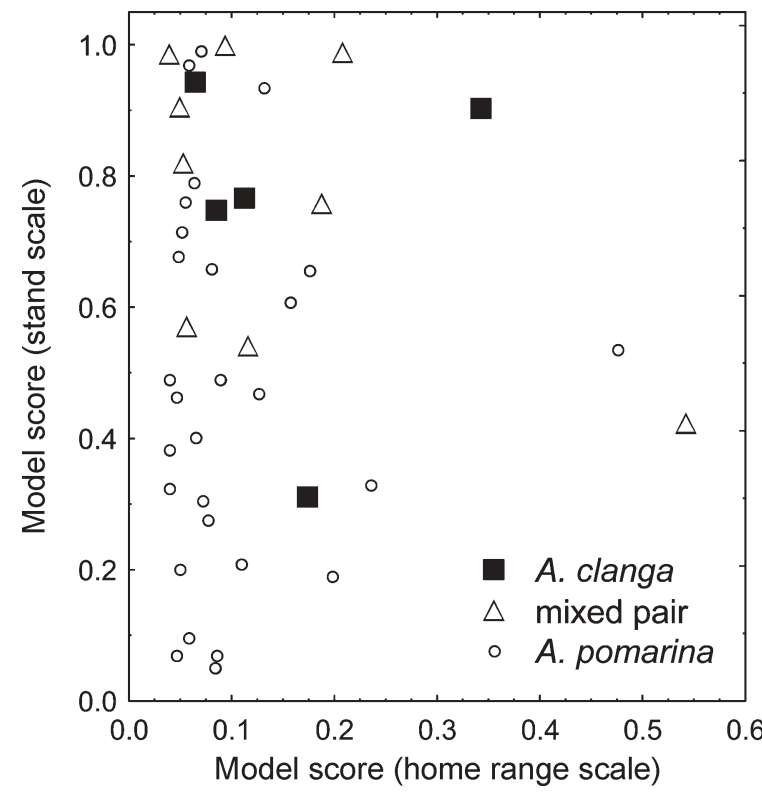

Fig. 3 Distribution of the nest sites of greater and lesser spotted eagles and their mixed pairs according to the values predicted by species-specific habitat models at home range and nest site scales (see Tables 2-3 for the models). A. pomarina points are shown only for comparison and are not meant to represent the whole population (the sample includes 14 sites near the nest sites of A. clanga and only 14 completely random sites).

the only taxonomically well-known mixed population of A. clanga, and we sampled at least $50-75 \%$ of the known A. clanga territories (Väli \& Lõhmus, 2000).
Although the habitats of $A$. clanga vary across its distribution area, the importance of natural grasslands, wetlands and old natural forests is evident throughout its European range. In addition to Estonia, the extant Polish, Ukrainian and Byelorussian populations are also concentrated in large riverine or marshland areas (Strigunov, 1986; Pugacewicz, 1995; Belik \& Vetrov, 1998; Dombrovski et al., 2000). In Ukraine the species has completely disappeared from hillsides and dry forests where it was previously common (Belik \& Vetrov, 1998), highlighting the importance of wetland habitat. The long history of agricultural development and deforestation in Europe is likely to have dramatically reduced the habitat for the species within the last two centuries.

The microhabitat preferences of $A$. clanga were less clear, because the independent contributions of several correlated features could have been concealed. The effect of the first principal component ('large spruce') probably reflects the eagle's preference for mature forest, which can be partly explained by the need for a large nest tree. The mean age (87 years, range 51-142 years) and diameter at breast height $(48 \mathrm{~cm}$, range $27-66 \mathrm{~cm}$; A. Lõhmus \& Ü. Väli, unpub. data) of 25 nest trees (the 22 in this study and three measured historically) in Estonia exceeds the mean values for trees at nest sites by $30-50 \%$. The eagle could probably also occupy younger forest if remnant trees were present, and retention of old trees during forestry operations could improve the supply of nest sites for the species.

Our new findings are the importance of a naturally diverse forest structure and a high degree of canopy closure. These two variables (Table 3 ) were better correlated with the occurrence of eagles than the swamp type of the stands. Nesting in wet forests has been considered characteristic of A. clanga (Pugacewicz, 1995; Ivanovsky, 1996; Maciorowski et al., 1996; Belik \& Vetrov, 1998). Possibly, swamps are simply the typical forest type in the wetland-rich home ranges of the eagles, and may not be specifically selected. A preference for old-growth structure, independent of stand age and composition, has been previously demonstrated for five other forestdwelling raptors, including $A$. pomarina (Lõhmus, 2003). This confirms that increasing structural diversity in forest increases the probability of raptor nesting and may be a successful restoration technique in degraded forests or plantations. A dense canopy has been considered a protection against overheating or predation in forest-dwelling raptors (Iverson et al., 1996; Selås, 1996; Krüger, 2002), and may make A. clanga vulnerable to thinning of nest stands. The dense nature of its nest stands has been mentioned also by Maciorowski et al. (1996) and Mischenko et al. (2001) in Poland and Russia, respectively. Both canopy closure (in the preference model) and old-growth structure (in the species segregation model) tended to gain significance after 
inclusion of other variables, particularly the first principal component ('large spruce'), which suggests that the internal structure of the stand may compensate for relatively young age or untypical tree composition.

The idea of partitioning of nesting habitat by the two spotted eagle species is not new (Pugacewicz, 1995; Ivanovsky, 1996) but we have quantified it for the first time and demonstrated it at both home range and nest site scales. Comparative studies on nest site characteristics of other sympatric tree-nesting raptors have repeatedly confirmed the theoretical prediction that species partition their habitat (or prey) to coexist (e.g. Schmutz et al., 1980; Bosakowski et al., 1992), including evidence of reduced habitat niches in the presence of competitors (Thiollay, 1993; Janes, 1994) or predators (Newton, 1986; Krüger, 2002). In all these cases either one of the species had a competitive advantage or the sympatric species had differing adaptations, whereas $A$. clanga and $A$. pomarina are similar morphologically and, at least in Estonia, largely share their foraging habitats and prey species (Väli \& Lõhmus, 2000; Lõhmus, 2001; Väli, 2003).

There are no studies on habitat determinants of the productivity of $A$. clanga (i.e. its nest site quality) and these data are difficult to collect for such a rare species. However, the role of habitat in the reproductive success of A. pomarina has been established (Lõhmus \& Väli, 2004). Given the similar reproductive parameters of the two species (clutch sizes, breeding frequencies, almost inevitable siblicide, and patterns of parental care; Cramp \& Simmons, 1980; Väli \& Lõhmus, 2002), a comparison of their reproductive rates in areas of sympatry could give an indication of the relative quality of their nest sites. In Estonia the recent average productivities of $A$. clanga and A. pomarina have been nearly identical $(0.60$ and 0.62 fledged young per occupied nest per year, respectively) and comparable with estimates from other regions (Väli \& Lõhmus, 2000; Väli, 2003). Mean habitat quality therefore seems to be sufficient for the extant pairs of both species in Estonia, and their distinct habitat preferences may reflect real preferences rather than the exclusion of one species by the other.

Given the habitat segregation between the two species, the absence of any obvious differences between the nest sites of pure and mixed pairs (Fig. 3) lends support to the suggestion that most interbreeding pairs are likely to occupy A. clanga territories (Lõhmus \& Väli, 2001), and suggests that habitat for $A$. clanga is unsaturated in Estonia. This requires further study. Whilst being at the edge of the distribution range or extensive shooting of the species on migration and wintering grounds (Meyburg et al., 2001) could explain the lack of adult birds, the fragmentation of natural landscapes over a certain threshold may have reduced territory occupancy rates (e.g. Lande, 1987). In either case, frequent mating of single adults with surplus birds from the surrounding, denser A. pomarina population is an expected consequence. The nest sites of interbreeding pairs currently deserve similar protection to that provided to A. clanga pairs, as this will ensure the maintenance of high-quality habitats for $A$. clanga pairs should their numbers recover in the future.

\section{Acknowledgements}

The study was financially supported by the Estonian Centre of Environmental Investments in the frame of the implementation of the national management plan for the greater spotted eagle. We thank Rimgaudas Treinys for commenting on the first draft of the manuscript.

\section{References}

Belik, V.P. \& Vetrov, V.V. (1998) Distribution and numbers of the greater spotted eagle in the steppe part of the Don watershed. In Materials of the 3rd Conference on Birds of Prey of Europe and Northern Asia, Part 1 (eds V.M. Galushin \& A.N. Khokhlov), pp. 7-8. Stavropol State University, Stavropol, Russia. [in Russian]

BirdLife International (2000) Threatened Birds of the World. Lynx Edicions and BirdLife International, Barcelona, Spain and Cambridge, UK.

Bosakowski, T., Smith, D.G. \& Speiser, R. (1992) Niche overlap of two sympatric-nesting hawks Accipiter spp. in the New Jersey-New York Highlands. Ecography, 15, 358-372.

Cramp, S. \& Simmons, K.E.L. (eds) (1980) The Birds of the Western Palearctic, Volume 2. Oxford University Press, Oxford, UK.

Dombrovski, V.C. (2002) Hybridization of lesser and greater spotted eagles (Aquila pomarina and A. clanga) in Belarus: rule or exception? Subbuteo, 5, 23-31.

Dombrovski, V.C., Tishechkin, A.K., Zhurauliov, D.V., Dzmitranok, M.G. \& Pinchuk, P.V. (2000) Breeding records of greater spotted eagle (Aquila clanga) in Central Palessie. Subbuteo, 3, 3-13.

Galushin, V.M. (1962) Greater spotted eagle in Oka valley and its impact on the numbers of some bird species. Uchenye Zapiski Moskovskogo Gosudarstvennogo Pedagogicheskogo Instituta, 186, 115-151. [in Russian]

Glotov, I.N. (1959) Data on the biology of Aquila clanga. Trudy Biologicheskogo Instituta Sibirskoe Otdelenie Akademiya Nauk SSSR, 5, 167-170. [in Russian]

Hosmer, D.W. Jr \& Lemeshow, S. (1989) Applied Logistic Regression. John Wiley, New York, USA.

IUCN (2004) IUCN Red List of Threatened Species. IUCN, Gland, Switzerland [http:/ / www.redlist.org, accessed 2 December 2004].

Ivanovsky, V. (1996) Notes on the breeding biology of spotted eagles Aquila clanga and A. pomarina in Byelorussia. In Eagle Studies (eds B.-U. Meyburg \& R.D. Chancellor), pp. 297-299. World Working Group on Birds of Prey and Owls, Berlin, Germany, London, UK and Paris, France.

Iverson, G.C., Hayward, G.D., Titus, K., DeGayner, E., Lowell, R.E., Crocker-Bedford, D.C., Schempf, P.F. \& Lindell, J. (1996) Conservation Assessment for the Northern Goshawk in 
Southeast Alaska. US Forest Service General Technical Report, PNW 387, Portland, USA.

Janes, S.W. (1994) Partial loss of red-tailed hawk territories to Swainson's hawks: relations to habitat. Condor, 96, 52-57.

Komischke, B., Graszynski, K. \& Meyburg, B.-U. (2001) Zur Biologie des Schelladlers Aquila clanga. Acta Ornithoecologica, $4,321-324$

Krüger, O. (2002) Analysis of nest occupancy and nest reproduction in two sympatric raptors: common buzzard Buteo buteo and goshawk Accipiter gentilis. Ecography, 25, 523-532.

Lande, R. (1987) Extinction thresholds in demographic models of territorial populations. American Naturalist, 130, 624-635.

Lõhmus, A. (2001) Selection of foraging habitats by birds of prey in north-western Tartumaa. Hirundo, 14, 27-42.

Lõhmus, A. (2003) Habitat preferences and habitat quality for birds of prey: from principles to applications. Dissertationes Biologicae Universitatis Tartuensis, 78. Tartu University Press, Tartu, Estonia.

Lõhmus, A. \& Väli, Ü. (2001) Interbreeding of the greater Aquila clanga and lesser spotted eagle A. pomarina. Acta Ornithoecologica, 4, 377-384.

Lõhmus, A. \& Väli, Ü. (2004) The effects of habitat quality and female size on the productivity of the lesser spotted eagle Aquila pomarina in the light of the alternative prey hypothesis. Journal of Avian Biology, 35, 455-464.

Maciorowski, G., Meyburg, B.-U., Matthes, J. \& Mizera, T. (1996) Breeding biology of the greater spotted eagle (Aquila clanga) in Poland. In Abstracts of 2nd International Conference on Raptors, pp. 35-36. Raptor Research Foundation, University of Urbino, Urbino, Italy.

Malchevskij, A.S. \& Pukinskij, Y.B. (1983) Birds of the Leningrad Region and Adjacent Territories, Part 1. Leningrad University Press, Leningrad, Russia. [in Russian]

Meiner, A. (ed.) (1999) Land Cover of Estonia. The Implementation of CORINE Land Cover Project in Estonia. Estonian Environment Information Centre, Tallinn, Estonia.

Meyburg, B.-U., Haraszthy, L., Strazds, M. \& Schäffer, N. (2001) European Species Action Plan for greater spotted eagle. In European Union Action Plans for Eight Priority Bird Species (eds N. Schäffer \& U. Gallo-Orsi). European Commission, Luxembourg.

Mischenko, A.L., Ochagov, D.M., Kostin, A.B., Galushin, V.M., Nikolaev, V.I., Sukhanova, O.V. \& Eremkin, G.S. (2001) Spotted eagles in the central part of European Russia: preliminary assessment of their ranges and population status. Acta Ornithoecologica, 4, 331-336.

Newton, I. (1986) The Sparrowhawk. Poyser, Calton, UK.

Panov, E.N. (1989) Natural Hybridisation and Ethological Isolation in Birds. Nauka, Moscow, Russia.

Pugacewicz, E. (1995) Population of the spotted eagle (Aquila clanga) in the Biebrza marshes in 1989-1993. Notatki Ornitologiczne, 36, 311-321.

Romanov, M.S. (2001) Factors influencing birds of prey distribution in forest landscapes of Bryansk region, Middle Russia. In Abstracts of the 4th Eurasian Congress on Raptors, p. 158. Estacion Biologica Donana, Raptor Research Foundation, Seville, Spain.
Scheller, W., Bergmanis, U., Meyburg, B.-U., Furkert, B., Knack, A. \& Röper, S. (2001) Raum-Zeit-Verhalten des Schreiadlers (Aquila pomarina). Acta Ornithoecologica, 4, 75-236.

Schmutz, J.K., Schmutz, S.M. \& Boag, D.A. (1980) Coexistence of three species of hawks (Buteo spp.) in the prairie-parkland ecotone. Canadian Journal of Zoology, 58, 1075-1089.

Selås, V. (1996) Selection and reuse of nest stands by sparrowhawks Accipiter nisus in relation to natural and manipulated variation in tree density. Journal of Avian Biology, 27, 56-62.

Shepel, A.I. (1992) Raptors and Owls of the Perm Region. University of Irkutsk Press, Irkutsk, Russia. [in Russian]

Steenhof, K. (1987) Assessing raptor reproductive success and productivity. In Raptor Management Techniques Manual (eds B.A.G. Pendleton, B.A. Millsap, K.W. Cline \& D.M. Bird), pp. 157-170. National Wildlife Federation, Washington, DC, USA.

Strigunov, V.I. (1986) Anthropogenic impacts on the raptor community in the forest-steppe zone in Ukraine. In Research on the Birds in the Soviet Union, their Conservation and Rationale Use, pp. 263-264. Zoological Institute of the Academy of Sciences of the Soviet Union, Leningrad, Russia. [in Russian]

Thiollay, J.-M. (1993) Habitat segregation and the insular syndrome in two congeneric raptors in New Caledonia, the white-bellied goshawk Accipiter haplochrous and the brown goshawk Accipiter fasciatus. Ibis, 135, 237-246.

Väli, Ü. (2003) The lesser spotted eagle and its conservation in Estonia. Hirundo Supplement, 6, 1-64.

Väli, Ü. \& Lõhmus, A. (2000) The greater spotted eagle and its conservation in Estonia. Hirundo Supplement, 3, 1-50.

Väli, Ü. \& Lõhmus, A. (2002) Parental care, nestling growth and diet in a spotted eagle Aquila clanga nest. Bird Study, 49, 93-95.

Väli, Ü. \& Lõhmus, A. (2004) Nestling characteristics and identification of the lesser spotted eagle Aquila pomarina, greater spotted eagle A. clanga, and their hybrids. Journal of Ornithology, 145, 256-263.

Väli, Ü., Treinys, R. \& Lõhmus, A. (2004) Geographical variation in macrohabitat use and preferences of the lesser spotted eagle Aquila pomarina. Ibis, 146, 661-671.

Zhezherin, V.P. (1969) On taxonomic interrelation of Aquila clanga Pall. and Aquila pomarina Brehm. Zbirnik Prats' Zoologichnogo Muzeyu (Kiev), 33, 91-97.

\section{Biographical sketches}

Asko Lõhmus' main research interests are forest ecology, wildlife-habitat relationships and conservation of birds, particularly raptors and owls. He leads the Conservation Biology working group at the University of Tartu and participates in the national planning of forest protection and species conservation in Estonia.

Ülo Väli is studying ecology, morphology and genetics of spotted eagles, and participates in conservation planning and implementation for these species in Estonia. 


\section{Appendix}

Variable means ( $\pm 95 \%$ confidence intervals, $C I$ ) at the home range and nest site scales and correlations of the variables with the principal components in random plots. See Table 1 for sample sizes.

\begin{tabular}{|c|c|c|}
\hline Variable & Mean $\pm 95 \%$ CI & Correlation coefficient with principal components* \\
\hline \multicolumn{3}{|l|}{ Home range scale } \\
\hline$\%$ forest within $2 \mathrm{~km}$ & $55.6 \pm 7.1$ & independent variable \\
\hline$\%$ open natural land within $2 \mathrm{~km}$ & $15.8 \pm 7.4$ & independent variable \\
\hline Landscape heterogeneity & $4.1 \pm 0.8$ & independent variable \\
\hline \multicolumn{3}{|l|}{ Distance $(\mathrm{m})$ to nearest: } \\
\hline Forest edge & $109 \pm 43$ & (D1)-0.74 \\
\hline Field or meadow & $268 \pm 170$ & (D1) -0.90 \\
\hline House & $673 \pm 159$ & (D1) -0.87 \\
\hline Road & $624 \pm 170$ & (D1) -0.63 \\
\hline Water body & $843 \pm 295$ & independent variable \\
\hline \multicolumn{3}{|l|}{ Nest site scale } \\
\hline$\%$ Scots pine Pinus sylvestris & $6.8 \pm 6.5$ & independent variable \\
\hline$\%$ Norway spruce Picea abies & $21.4 \pm 10.8$ & (S1) 0.65 \\
\hline$\%$ aspen Populus tremula & $11.4 \pm 8.4$ & \\
\hline$\%$ black alder Alnus glutinosa & $15.7 \pm 8.6$ & (S2) 0.67 \\
\hline$\%$ grey alder Alnus incana & $8.2 \pm 7.5$ & $(\mathrm{~S} 2)-0.59$ \\
\hline$\%$ birch Betula spp. & $31.4 \pm 11.0$ & (S1)-0.55; (S2) 0.49 \\
\hline Stand age (years) & $67.5 \pm 7.1$ & (S1) $0.74 ;(\mathrm{S} 2) 0.50$ \\
\hline Old-growth structure (scale of 4-12) & $8.1 \pm 0.8$ & independent variable \\
\hline Tree height $(\mathrm{m})$ & $22.3 \pm 1.2$ & (S1) 0.52 \\
\hline Tree diameter at breast height $(\mathrm{cm})$ & $31.7 \pm 2.5$ & (S1) 0.83 ; (S2) 0.34 \\
\hline Soil moisture class (scale of $1-4$ ) & $3.1 \pm 0.3$ & (S2)-0.52; (S2) 0.42 \\
\hline Canopy closure (scale of $0-1$ ) & $0.7 \pm 0.1$ & independent variable \\
\hline
\end{tabular}

*The principal components were extracted separately for the distances (D1) and forest (S1, S2) characteristics. Prior to the extraction, distance to road was square-root transformed, other distances log-transformed, and proportions arcsine-square-root transformed. Weak correlations $(r=-0.3-0.3)$ are not shown. In the text and Tables 2-3 the principal component D1 is referred to as 'fragmentation', and S1 and S2 as 'large spruce' and 'alder swamp', respectively. 